\title{
IMPACT OF LAPORSCOPIC OVARIAN DRILLING ON HORMONAL PROFILE OF PATIENTS WITH POLYCYSTIC OVARY SYNDROME
}

\author{
By \\ Abd El-Monem Mohamed Zakareya, Ashraf Hamdy Mohamed and \\ Haitham Hendawy Hussen Shehab \\ Departemnt of Obstetrics and Gynecology, Faculty of Medicine, Al-Azhar Cairo \\ University
}

\begin{abstract}
Background: Polycystic ovary syndrome (PCOS) is complex with reproductive, metabolic and psychological features. It is characterized by chronic anovulation, biochemical and/or clinical evidence of hyperandrogenism and enlarged ovaries.

Objective: Is to evaluate the effect of ovarian drilling on the hormonal profile levels on blood in women with polycystic ovary syndrome. Hormonal profile including: Serum FSH, LH, E2, Prolactin and androgens (total $\&$ free testosterone and dehydroepiandrosterone sulfate (DHEA-S).

Patients and Methods: Fifty infertile women diagnosed with PCOS attending the infertility outpatient clinic at Syed Galal university hospital were selected for prospective interventional study. Hormonal assessment for FSH, LH, E2, prolactin and androgens (total \& free test oster on and DHEA-S) were done before laparoscopic ovarian drilling (LOD), and 3month after LOD. Main outcome measures were changes in hormonal profile including LH, LH/FSH ratio, E2, Prolaction and androgens (total \&free testosterone and DHEA-S).
\end{abstract}

Results: Laparoscopic ovarian drilling (LOD) was successfully employed without any surgical complications and on an average, follow-up time three months after the procedure. During the follow up, serum values for prolaction and E2 have increased significantly. (LH, LH/FSH ratio, total \& free Testosterone and DHEA-S) have decreased significantly and FSH levels remained unchanged after the procedure.

Conclusion: The LOD in patients with PCOS may avoid or reduce the risk of OHSS and the multiple pregnancy rate induced by gonadotrophin therapy and the cost effectiveness of procedure after an attractive management for patients with PCOS. However, LOD can be considered as second line treatment after clomiphene citrate treatment failure and /or resistance.

Keywords: Polycystic ovary Syndrome - Anovulation - Infertility -laparoscopic ovarian drilling.

\section{INTRODUCTION}

polycystic Polycystic ovary syndrome (PCOS) is the most common endocrinopathy affecting reproductive aged women, with prevalence of between $6 \%$ and $15 \%$ of women of reproductive age and account for 72-84 \% of adult hyperandrogenim (Fauser et al., 2012).
Three international conferences have developed somewhat different but overlapping diagnostic criteria for adult women: the National Institutes of Health (NIH) conference criteria (1990), the Rotterdam consensus criteria (2003) (Rotterdam ESHRE/ASRM-sponsored PCOS Consensus Workshop Group 2004), 
and the Androgen Excess-PCOS-Society consensus criteria (Azziz et al., 2009).

The Rotterdam criteria are the broadest and include the feature of other definitions. They allow PCOS to be diagnosed with a combination of chronic anovulation and polycystic ovary morphology (PCOSM) without hyperandrogenism (Conway et al., 2014).

Although the pathogenesis of PCOS syndrome is unknown, but it is believed that PCOS is result of different interaction between genetic and multiple environmental factors. This syndrome is multi-factorial disease, and the different susceptibility of patients is probably determined by several genetic and environmental risk factor (Spritzer, 2014 and Tsikouras et al., 2015).Specifically an increased prevalence has been noted between affected individuals and their sisters (32 to 66\%) and mothers (24 to 52\%) (Lenarcik et al., 2011).

Some have suggested an autosomal dominant inheritance with expression in both females and males, for example; first degree male relative of women with PCOS have been shown to have significantly higher circulating dehydroepiandrosterone sulfate (DHEAS) levels than control males (Goodarzi et al., 2015).

Clinical practice in the assessment and management of PCOS is inconsistent, with key evidence practice gaps, whilst women internationally have highlighted delayed diagnosis and dissatisfaction with care (Gibson-helm et al., 2017).

The American College of Obstetricians and Gynecologists (ACOG) recommend clomiphene citrate (CC) is the classic first line used in ovulation induction in PCOS patients with ovulation rate $70-80 \%$ and pregnancy rate $40 \%$ when fertility is desired (Vause et al, 2010). Second line intervention includes either exogenous gonadotropins or LOD. Exogenous gonadotropinsis highly effective but risk of multiple pregnancies (careful monitoring is must) (Moazami Goudari et al., 2014).

Laparoscopic ovarian drilling (LOD) is one mode of surgical therapy used for inducing ovulation, it is associated with less trauma and fewer postoperative adhesions (Farquhar, 2012).

The cause of disparity may be due to post-operative adhesion formation, postLOD hyperprolactinemia and unknown reasons (Nahuis et al., 2012).

Laparoscopic ovarian drilling replaced ovarian wedge resection as surgical treatment for woman with polycystic ovarian syndrome (Farquhar et al., 2012). It is free of risks of multiple pregnancies, ovarian hyperstimulation, and does not require intensive ultrasound monitoring. Furthermore, ovarian diathermy appears to be as effective as routine gonadotropin therapy in the treatment of women with polycystic ovarian syndrome, in addition, laparoscopic ovarian drilling is useful therapy for an ovulatory women with polycystic ovarian syndrome who failed to respond to clomiphene citrate and who either persistently hypersecretae $\mathrm{LH}$ or who live too far away from the hospital to be able to attend for the intensive monitoring required for gonadotropin therapy (Mayenga et al., 2011).

The aim of this study was to evaluate the effect of the ovarian drilling on the 
hormonal profile levels on blood in women with polycystic ovary syndrome.

\section{PATIENTS AND METHODS}

This was a prospective interventional study to evaluate the impact of ovarian drilling on the hormonal profile on blood in women with polycystic ovary syndrome. Hormonal profile including: serum FSH, LH, prolactin, E2 and androgens (total \& free testosterone and DHEA-S). Women who agreed to participate in the study were informed about the nature of the study, the investigations they will undergo and its timing.

This study was carried out in department of Obstetrics and Gynecology, Endoscopy unit at Sayed Galal university hospital in period between February 2018 and July 2019. It was conducted on 50 infertile women diagnosed with polycystic ovary syndrome (PCOS) attending the infertility outpatient clinic at Sayed Galal university hospital. They were candidate for laparoscopic ovarian drilling.

\section{All patients were submitted to:}

- Written consent was taken from every woman participating in this study

- Full history taking and careful examination.

- Thorough history taking.

- Complete physical examination.

\section{Investigations:}

a. Ultrasound (Aloka prosound $\alpha 7$, Japan, 2015) vaginal ultrasound to confirm the criteria suggestin polycystic ovary syndrome and to exclude pregnancy.

b. FSH, LH levels \& E2. (Day 2 or 3 days after the commencement of spontaneous or progesterone induced menstrual bleeding.

c. Androgens (testosteroneTotal \& Free \& DHEA-S).

d. Prolactin level was measured in all patients (to exclude hyperprolactinemia and to take the value as a control).

Laparoscopic ovarian drilling procedure was made to every patient.

The patients were discharged on the same day of operation and follow up was done by transvaginal U/S (folicumetry, to detect ovulation) and after three months for prolactin hormone level evaluation using the same instructions and precautions as in the first sample.

NB:Obese and multiple scar ladies were operated upon using open laparoscopic technique.

Post-operatively (Three months after operation): All previous hormonal profile was rechecked three months after operation.

\section{Statistical analysis:}

Data were fed to the computer and analyzed using IBM SPSS software package version 20.0. (Armonk, NY: IBM Corp) Qualitative data were described using number and percent. The Kolmogorov-Smirnov test was used to verify the normality of distribution Quantitative data were described using range (minimum and maximum), mean, standard deviation and median. Significance of the obtained results was judged at the $5 \%$ level. 


\section{The used tests were:}

1. Paired t-test: For normally distributed quantitative variables, to compare between two periods.
2. Wilcoxon signed ranks test: For abnormally distributed quantitative variables, to compare between two periods.

\section{RESULTS}

This study was conducted on 50 infertile Women with PCOS among those attending the infertility outpatient clinic at Sayed Galal university hospital and was candidate for LOD at endoscopy unit to show its effect on hormonal profile. However, 6 cases were excluded from the statistical analysis because they got pregnant. The results were summarized and grouped in tables and figures for illustration as follow: Homonal profile including $\mathrm{LH}, \mathrm{FSH}, \mathrm{E} 2$, Prolactin, Androgens (total, free testosterone and DHEA-S) were done for all patients befor and after LOD.

Demographic data of the studied patients showed that average age of the studied cases was 27.5 year and $26 \%$ of the studied women were obese (Table 1).

Table (1): Demographic data of the studied patients

\begin{tabular}{|c|c|c|}
\hline $\begin{array}{ll}\text { Parameters } & \text { Count } \\
\end{array}$ & No. & $\%$ \\
\hline $\begin{array}{l}\text { Age (years): } \\
<25\end{array}$ & 11 & 22.0 \\
\hline $25-30$ & 25 & 50.0 \\
\hline$>30$ & 14 & 28.0 \\
\hline Min. - Max. & \multicolumn{2}{|c|}{$21.0-35.0$} \\
\hline Mean \pm SD. & \multicolumn{2}{|c|}{$27.56 \pm 3.74$} \\
\hline Median & \multicolumn{2}{|c|}{27.50} \\
\hline $\begin{array}{l}\text { BMI }\left(\mathbf{k g} / \mathbf{m}^{2}\right): \\
\text { Normal }(<25)\end{array}$ & 15 & 30.0 \\
\hline Overweight $(25-<30)$ & 22 & 44.0 \\
\hline Obese $(\geq 30)$ & 13 & 26.0 \\
\hline Min. - Max. & \multicolumn{2}{|c|}{$21.15-36.16$} \\
\hline Mean \pm SD. & \multicolumn{2}{|c|}{$27.94 \pm 4.04$} \\
\hline Median & \multicolumn{2}{|c|}{27.93} \\
\hline
\end{tabular}

There was a significant decrease in serum LH levels from $11.64 \pm 3.58$ before drilling to $6.77 \pm 1.70$ after drilling. Also, there was a significant change in LH/FSH ratio from $1.90 \pm 0.38$ before drilling to $1.14 \pm 0.17$ after drilling. We noticed that there was insignificant change in serum FSH levels from $6.09 \pm 1.35$ before drilling to $5.96 \pm 1.16$ after drilling. We noticed that there was a significant increase in serum prolactin levels from $14.40 \pm 5.18$ before drilling to $17.59 \pm$ 5.05 after drilling. We noticed that there was a significant increase in serum E2 levels from $30.18 \pm 14.14$ before drilling to $63.74 \pm 15.71$ after drilling. We noticed that there was a significant decrease in serum total testosterone from $0.41 \pm 0.29$ before drilling to $0.16 \pm 0.07$ after drilling. Also, we noticed that there was a 
significant decrease in serum free testosterone from $5.25 \pm 1.16$ before drilling to $2.47 \pm 0.67$ after drilling. We noticed that there was a significant decrease in serum DHEA-S from $192.0 \pm$ 33.02 before drilling to $180.4 \pm 30.26$ after drilling (Table 2).

Table (2): Hormonal profile of the participants before and after LOD

\begin{tabular}{|c|c|c|c|}
\hline Hormonal profile $\quad$ LOD & Before LOD & After LOD & $\mathbf{P}$ \\
\hline LH $(\mathbf{m I u} / \mathbf{m l})$ & & & \\
\hline Min. - Max. & $6.10-20.20$ & $4.20-10.50$ & \multirow{3}{*}{$<0.001$} \\
\hline Mean \pm SD. & $11.64 \pm 3.58$ & $6.77 \pm 1.70$ & \\
\hline Median & 11.0 & 6.35 & \\
\hline FSH $(\mathbf{m I u} / \mathrm{ml})$ & & & \\
\hline Min. - Max. & $3.90-9.15$ & $3.90-8.90$ & \multirow{3}{*}{0.075} \\
\hline Mean \pm SD. & $6.09 \pm 1.35$ & $5.96 \pm 1.16$ & \\
\hline Median & 6.12 & 5.90 & \\
\hline LH/FSH ratio & & & \multirow{4}{*}{$<0.001$} \\
\hline Min. - Max. & $1.07-2.60$ & $0.74-1.46$ & \\
\hline Mean \pm SD. & $1.90 \pm 0.38$ & $1.14 \pm 0.17$ & \\
\hline Median & 1.94 & 1.14 & \\
\hline $\begin{array}{l}\text { Prolactin }(\mathbf{n g} / \mathbf{m l}) \\
\text { Min. - Max. } \\
\text { Mean } \pm \text { SD. } \\
\text { Median }\end{array}$ & $\begin{array}{c}6.0-25.0 \\
14.40 \pm 5.18 \\
14.10\end{array}$ & $\begin{array}{c}6.0-26.70 \\
17.59 \pm 5.05 \\
18.0\end{array}$ & 0.001 \\
\hline $\begin{array}{l}\text { E2 }(\mathbf{p g} / \mathbf{m l}) \\
\text { Min. - Max. } \\
\text { Mean } \pm \text { SD. } \\
\text { Median }\end{array}$ & $\begin{array}{c}18.0-95.0 \\
29.86 \pm 12.34 \\
28.21\end{array}$ & $\begin{array}{c}30.0-100.0 \\
38.29 \pm 12.45 \\
33.0\end{array}$ & $<0.001$ \\
\hline $\begin{array}{l}\text { Total Testosterone }(\mathbf{n g} / \mathbf{m l}) \\
\text { Min. - Max. } \\
\text { Mean } \pm \text { SD. } \\
\quad \text { Median }\end{array}$ & $\begin{array}{l}0.10-2.29 \\
0.41 \pm 0.29 \\
0.40\end{array}$ & $\begin{array}{c}0.16 \pm 0.07 \\
0.16 \pm 0.07 \\
0.15\end{array}$ & $<0.001$ \\
\hline $\begin{array}{l}\text { Free Testosterone }(\mathbf{p g} / \mathbf{m l}) \\
\text { Min. }- \text { Max. } \\
\text { Mean } \pm \text { SD. } \\
\text { Median }\end{array}$ & $\begin{array}{l}2.01-6.90 \\
5.25 \pm 1.16 \\
5.77\end{array}$ & $\begin{array}{l}1.48-4.30 \\
2.47 \pm 0.67 \\
2.16\end{array}$ & $<0.001$ \\
\hline $\begin{array}{l}\text { DHEA-S }(\boldsymbol{\mu g} / \mathbf{d l}) \\
\text { Min. }- \text { Max. } \\
\text { Mean } \pm \text { SD. } \\
\text { Median }\end{array}$ & $\begin{array}{c}112.0-270.4 \\
192.0 \pm 33.02 \\
195.0\end{array}$ & $\begin{array}{c}108.0-254.9 \\
180.4 \pm 30.26 \\
184.5\end{array}$ & $<0.001$ \\
\hline
\end{tabular}

$\mathrm{p}$ : $\mathrm{p}$ value for comparing between before and after

\section{DISCUSSION}

Polycystic ovarian syndrome encompasses a heterogeneous group of condition and the diagnosis is based on different parameters by different investigations.
In our study we included cases with frank PCOS (hyperandrogenism, chronic anovulation and polycystic ovaries by ultrasound). We tried to establish the biophysical and endocrine factors that influenced the outcome of laparoscopic 
ovarian drilling in carefully diagnosed subjects with CC-resistant PCOS based on criteria mentioned above.

There was a decrease on the values of LH, LH/FSH ratio, total \&free testosterone and DHEA-S, but the values of prolactin and E2 increased significantly, and FSH levels remained unchanged after laparoscopic ovarian drilling.

Level of LH, LH-to-FSH ratio and testosterone(free \& total) and the mean level of FSH before and after dilling, were in agreement with that of Elmashed (2011), Onofriescu et al. (2012), Aboelghar et al. (2014), Elsamy \& Saleh (2015) and Elnaggar \& Abo Elwan (2016).

On contrary to our findings, Onofriescu et al. (2012) reported a significant rise of FSH level after LOD through long duration of follow up. The cause of elevation could be due to:

- Long duration of follow-up may be more than 12 months.

- Different technique of laparoscopic ovarian drilling.

- They had conducted their studies on different age group, different patient number and different patient criteria.

The increase of serum prolactin after LOD that we had found in our study came in consistence with the study done by Elsamy and Saleh (2015). Kriplani et al. (2011) and Elnaaggar \& Abo Elwan (2016) observed decrease in serum Prolactin level after LOD. This may be due to operative stress that causes an elevated prolactin level which is a common finding during and after operation with the peak of prolactin levels.

\section{CONCLUSION}

Laparoscopic ovarian drilling was very useful when CC fails in patient with PCOS. Most of abnormalities of hormonal profile associated with polycystic ovary syndrome were corrected by LOD.These changes may help in inducing ovulation and avoiding Ovarian hyperstimulation syndrome.

\section{RECOMMENDATION}

- Laparoscopic ovarian drilling should be considered as second line- therapy in all cases that do not respond in 4month time to Clomiphene citrate therapy.

- However, further studies with large sample size, additional data and long term follow-up period is required to evaluate the effect of LOD and the hormonal changes following laparoscopic ovarian drilling in polycystic ovary syndrome patients.

\section{REFERENCES}

1. Abuelghar WM, Bayoumy HA, Ellaithy MI and Khalil MS. (2014): Women with clomiphene citrate resistant polycystic ovarin disease: predictors of spontaneous ovulation after laparoscopic ovarian drilling. Eur J Obstet Gynecol Reprod Biol., 175:178-85.

2. Azziz R, Carmina E, Dewailly D, Diamanti-Kandarakis E, EscobarMorreale HF, Futterweit W, Janssen OE, Legro RS, Norman RJ, Tylor AE and Witchel SF. (2009): The Androgen Excess and PCOS Society Criteria for the 
polycystic ovary syndrome: The compelet task force report. Fetril Steril., 91(2):456-88.

3. Conway G, Dewailly D, DiamantiKandarakis E, Escobar-Macut D, Morreale HF, Franks S, Gambineri A, Kelestimur F, Macut D, Micic D, Pasquali R, Pfeifer M, Pignatelli D, Pugest $M$ and Yildiz BO (2014): ESE PCOS Special Interest Group:The polycystic ovary syndrome: a position statement from the European society of Endocrinology. Eur J Endocrinol., 171:1-29.

4. Elmashad AI. (2011): Impact of laparoscopic ovarian drilling on antiMullerian hormone levels and ovarian stromal blood flow using threedimensional power Doppler in women with anovulatory polycystic ovary syndrome. Fertil Steril., 95(7):2342-6.

5. Elnaaggar $\mathbf{E}$ and Abo Elwan $\mathbf{Y}$. (2016): Hormonal change after laparoscopic ovarian diathermy in patients with polycystic ovarian syndrome.J Obstet Gynecol., 66(S1):S528-33.

6. Elsamy E and Saleh S. (2015): Impact of laparoscopic ovarian drilling on hormonal profile and clinical features in women with polycystic ovary sendrome. Int $\mathbf{J}$ Gynecol Obstet., 20(1): 1-5.

7. ESHRE/ASRM, Rotterdam Consensus Workshop Group (2003): Revised 2003 consensus on diagnostic crirteia and long-term health risks related to polycystic ovary syndrome. Fertil Steril., 81(1):19-25.

8. Farquhar C, Brown $J$ and Marjoribanks J. (2012): Laparoscopic "drilling" by diathermy or laser for ovulation induction in anovulatory polycystic ovary syndrome. Cochrane Database Syst Rev., (6):CD001122.

9. Fauser BC, Tarlatzis BC, Rebar RW, Legro RS, Balen AH, Lobo R, Carmina E, Chang J, Yildiz BO, Laven JS, Boivin J, Petraglia F, Wijeyeratne CN, Norman RJ, Dunaif A, Franks S,Wild RA, Dumesic D and Barnhart k. (2012): Consensus on women's health aspects of polycystic ovary syndrome (PCOS): the Amsterdam ESHRE/ASRM-Sponsored 3rd PCOS Consensus workshop Group. Fertil Steril., 97:28-38.

10. Gibson-Helm M, Teede H, Dunaif A, Dokras A and Dokras A. (2017): Delayed diagnosis and lack of information associated with dissatisfaction in women with polycystic ovary syndrome. J Clin Endocinol Metab., 102(2):604-12.

11. Goodarzi MO, Carmina $E$ and Azziz R. (2015): DHEA, DHEA-S and PCOS. J Steroid Biochem Mol Biol., 145:213-25.

12. Kriplani A, Manchanda $R$, Agarwal N and Nayar B. (2011): Laparoscopic ovarian drilling in clomiphene citrate-resistant women with polycystic ovary syndrome. J Am Assoc Gynecol Laparosc., 8(4):511-8. 
13. Lenarcik A, Bidzinska-Speichert B, Tworowska-Bardzinska $U$ and Krepula K. (2011): Hormonal abnormalities in first -degree relatives of women with polycystic ovary syndrome (PCOS). Endokrynol Pol., 62(2):129-33.

14. Mayenga JM, Grzegorczyk Martin V and Belaisch-Allart J. (2011): The place of ovarian drilling in the mangement of polycystic ovarian syndrome (PCOS). Gynecol Obstet Fertil., 39(9):518-20.

15. Moazami Goudarzi Z, Fallahzadeh $\mathrm{H}$, Aflatoonian $\mathrm{A}$ and Mirzaei $\mathrm{M}$. (2014): Laparoscopic ovarian electrocautery versus gonadotropin therapy in infertile women with clomiphene citrate-resistant polycystic ovary syndrome: A systematic review and meta- analysis. Iran J Reprod Med., 12(8):531-8.

16. Nahuis MJ, Oude Lohuis E, Kose $\mathbf{N}$, Bayram $\mathbf{N}$, Hompes $\mathbf{P}$ and Oosterhuis GJ. (2012): Long-term follow-up of laparoscopic electrocautery of ovaries versus ovulation induction with recombinant FSH in clomiphene citrate-resistant women with polycystic ovary syndrome: an economic evaluation. Hum Reprod., 27(12):3577-82.

17. Onofriescu A,Dragos Nemescu D,Onofriescu $M$ and Carmen Vulpoi C (2012): Lparoscopic ovarian drilling for polycystic ovarian syndrome.TMJ, 62:1-2.

18. Spritzer PM (2014): Polycystic ovary syndrome. Arq Bras Endocinol Metab., 58:182-7.

19. Tsikouras P, Spyros L, Manav B, Zervoudis S, Poiana C, Nikolaos T, Petros P, Dimitraki M, Koukouli C, Galazios $G$ and von Tempelhoff GF. (2015): Features of Polycystic Ovary Syndrome in adolescence. $\mathbf{J}$ Med Life., 8(3):291-6.

20. Vause TD, Cheung AP, Sierra S and Claman P. (2010): Ovulation induction in polycystic ovary syndrome. J Obstet Gynecol Can., 32(5):495-502. 


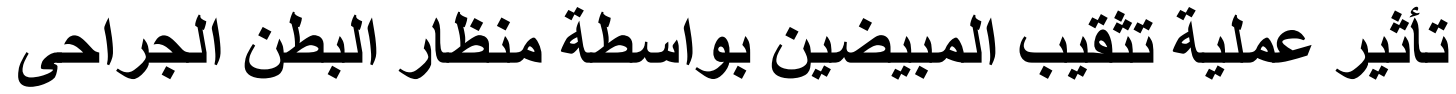

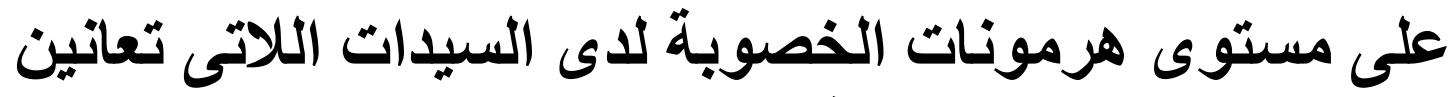 من متلازمة تكيسات المبيضين}

عبدالمنعم محمد زكريا، أشرف حمدى محمد، هيثم هنداوى حسين شهاب

قسم التوليد وأمر اض النساء، كلية الطب، جامعة الأزهر بالقاهرة

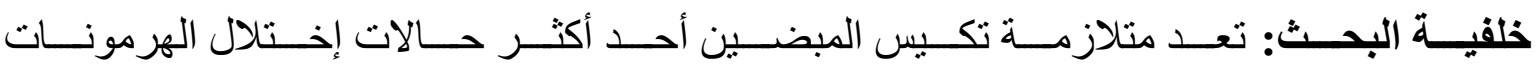

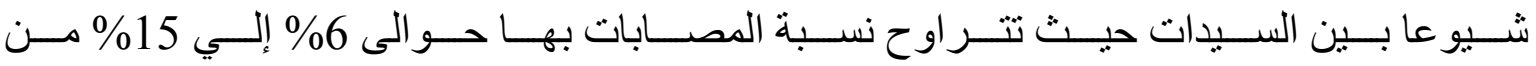

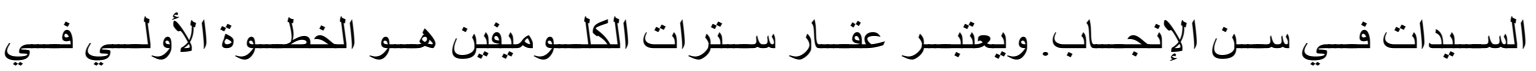

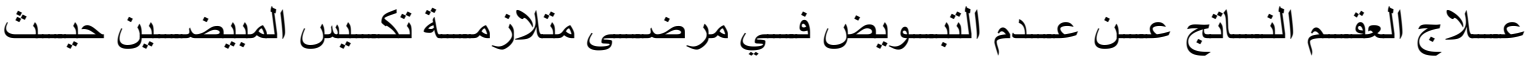

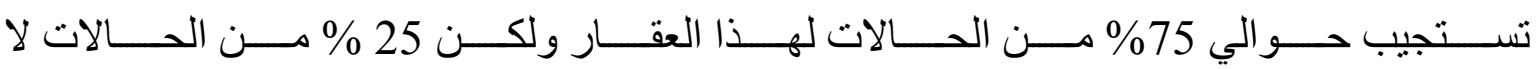

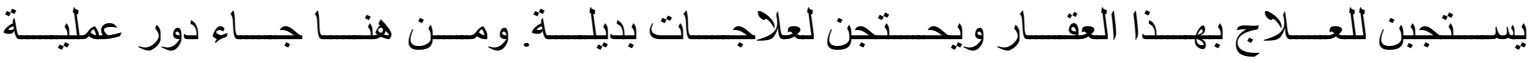

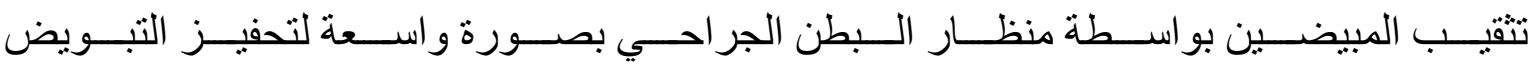

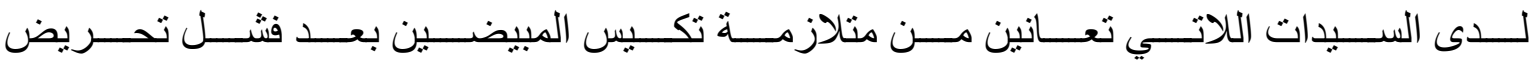
التبويض بو اسطة عقار سترات الكلوميفين.

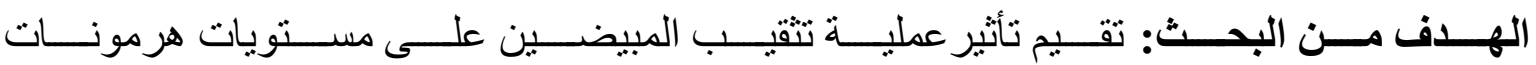
الخصوبة لدى السيدات اللاتي تعانين من متلازمة تكيس المبيضين.

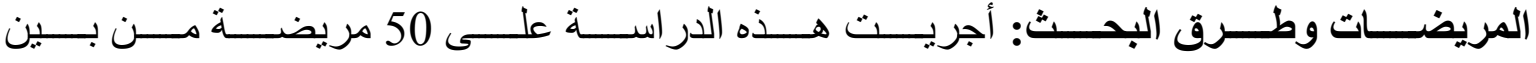

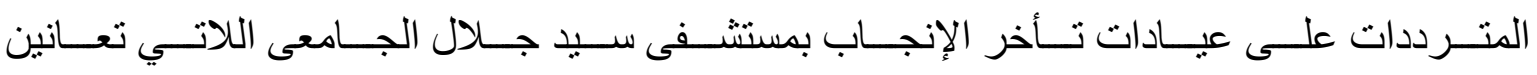

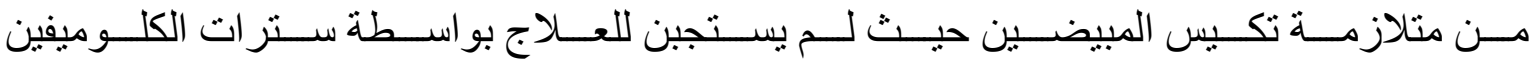

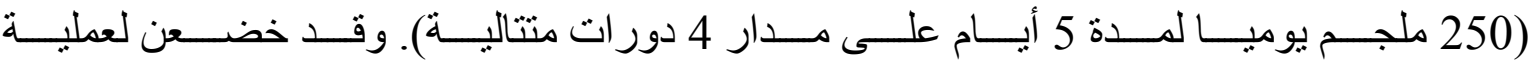

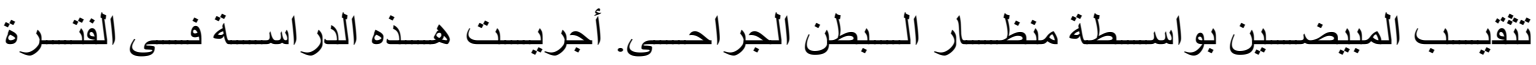
من فبراير 2017 حتى يوليو 2019.

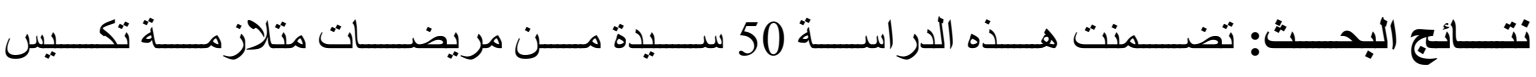

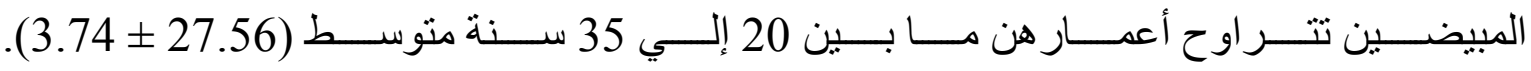

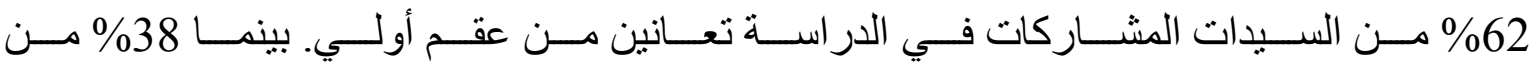

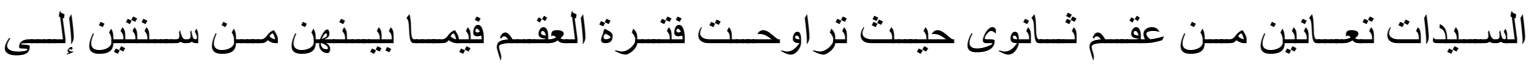




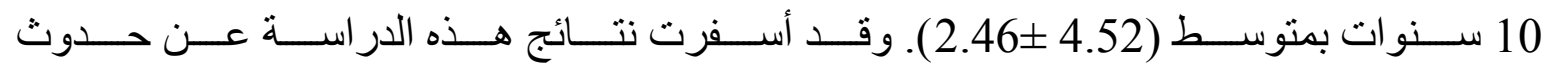

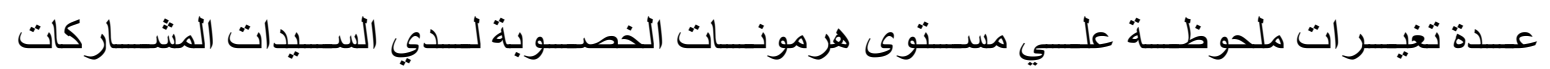
في هذه الدر اسة.

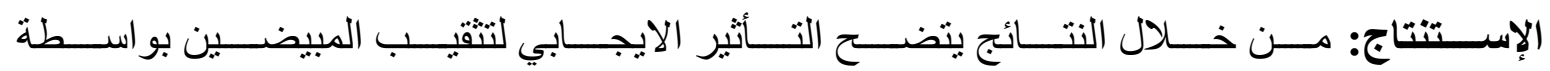

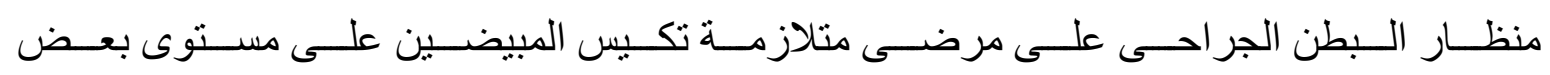

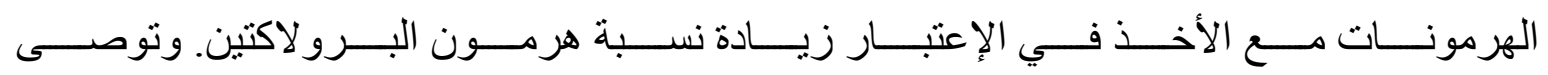

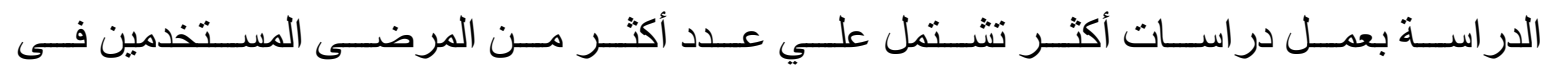

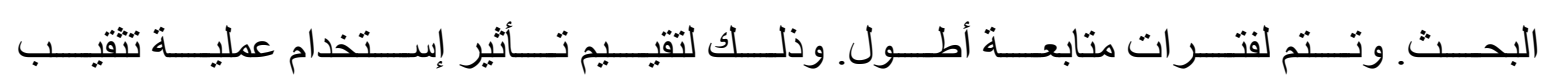

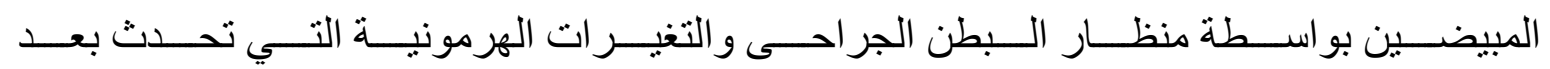
إجر اء هذه العملية في مرضي تكيس المبيضين. 